\title{
Intravenous Immunoglobulin (IVIG) Treatment for Modulation of Immune Activation in Human Immunodeficiency Virus Type 1 Infected Therapy-Naive Individuals
}

\author{
JOOST N. VERMEULEN,,${ }^{1,2}$ JAN M. PRINS, ${ }^{2}$ EVELIEN BUNNIK, ${ }^{3}$ C. ERIK HACK, ${ }^{3, *}$ \\ SUZANNE JURRIAANS,${ }^{4}$ FRANK MIEDEMA, ${ }^{3,5}$ JOEP M.A. LANGE, ${ }^{1,2}$ \\ and HANNEKE SCHUITEMAKER ${ }^{3}$
}

\begin{abstract}
We evaluated the ability of intravenous immunoglobuline (IVIG) to diminish immune hyperactivation, which is considered a major cause of $\mathrm{CD}^{+}{ }^{+} \mathrm{T}$ cell loss during chronic HIV-1 infection and whether this affected $\mathrm{CD4}^{+} \mathrm{T}$ cell counts and plasma HIV-1 RNA $(\mathrm{pVL})$. Therefore, we treated six chronically HIV-1-infected, antiretroviral-therapy-naive patients with IVIG $(0.4 \mathrm{~g} / \mathrm{kg})$ at weeks 0 and 4 , with a follow-up of 12 weeks after the second dosage during which $\mathrm{pVL}$, $\mathrm{T}$ cell numbers, and $\mathrm{T}$ cell activation were measured. At baseline median $\mathrm{CD}^{+} \mathrm{T}$ cell counts were 300 (range 200-460) $\times 10^{6}$ /liter and median pVL was 5.0 (range 3.2-5.2) $\log _{10}$ copies/ml. IgG plasma levels peaked during the first days after administration. We observed a decrease in the

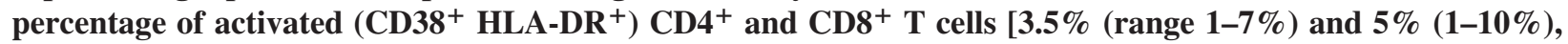
respectively $(p=0.027)]$, but no effect on the fraction of proliferating $\mathrm{CD4}^{+}$or $\mathrm{CD8}^{+} \mathrm{T}$ cells as measured by Ki67 expression. $\mathrm{CD4}^{+} \mathrm{T}$ cell counts were significantly increased on day 4 (median +55 cells, range $0-150$, $p=0.043$ ). $p$ VL was significantly increased on day 1 after IVIG infusion (median $+0.13 \log _{10}$, range $0.01-0.55$, $p=0.028$ ). All these parameters returned to baseline levels within 1 week after infusion. In conclusion, administration of IVIG caused a temporary decrease in $\mathrm{T}$ cell activation and an increase in $\mathrm{CD}^{+} \mathrm{T}$ cell counts, despite an increase in pVL. Our results support the hypothesis that $\mathrm{T}$ cell activation, rather than direct HIV1 infection, mediates the loss of $\mathrm{CD}^{+}{ }^{+} \mathrm{T}$ cells and suggest that immunomodulating therapy in $\mathrm{HIV}-1$ infection could indeed be effective.
\end{abstract}

$\mathbf{T}$ HE OUTLOOK FOR HIV-1-INFECTED INDIVIDUALS has improved tremendously since the introduction of highly active antiretroviral therapy (HAART) in the mid-1990s. ${ }^{1-4}$ However, the use of HAART is limited by toxicity, high costs, the need for strict adherence to the medication, and the risk of development of viral resistance against the antiretroviral drugs. Therefore, the search for alternative treatment strategies is ongoing.
The hallmark of disease progression in chronic HIV-1 infection is the loss of $\mathrm{CD}^{+}{ }^{+} \mathrm{T}$ cells. The percentage of circulating $\mathrm{CD}^{+}{ }^{+} \mathrm{T}$ cells infected with HIV-1 is too low to explain this loss by direct cytopathic effects of HIV-1., ${ }^{5,6}$ The current hypothesis is that HIV-1 leads to massive depletion of $\mathrm{CD}^{+}$ $\mathrm{T}$ cells in lymphoid tissue in the gastrointestinal tract, especially during the acute phase of the infection. ${ }^{7}$ During chronic infection continuous hyperactivation of the immune system leads to

\footnotetext{
${ }^{1}$ IATEC, Amsterdam, the Netherlands.

${ }^{2}$ Center for Poverty-related Communicable diseases, Department of Internal Medicine, Center for Infection and Immunity Amsterdam, Academic Medical Center, University of Amsterdam, Amsterdam, the Netherlands.

${ }^{3}$ Sanquin Research and Landsteiner Laboratory, Center for Infection and Immunity Amsterdam, University of Amsterdam, Amsterdam, the Netherlands.

${ }^{4}$ Department of Human Retrovirology, Academic Medical Center, Center for Infection and Immunity Amsterdam, University of Amsterdam, Amsterdam, the Netherlands.

${ }^{5}$ University Medical Center Utrecht, Utrecht, the Netherlands.

*Present address: Crucell Holland B.V., Leiden, the Netherlands.
} 
enhanced $\mathrm{T}$ cell turnover and exhaustion of the naive $\mathrm{T}$ cell compartment. ${ }^{8}$ HIV-1 activates the immune system because of the high virion production and possibly by viral products. ${ }^{8,9}$ Activated and proliferating T cells in HIV-1-infected patients have a short half life and die after several rounds of division. ${ }^{10,11}$ The proportion of activated and proliferating cells is a strong predictor of disease progression. ${ }^{12}$

Suppression of viral replication by HAART prevents the loss of $\mathrm{CD}^{+} \mathrm{T}$ cells by preventing new infections of $\mathrm{CD} 4^{+} \mathrm{T}$ cells, but mainly by reducing the antigenic trigger that leads to immune activation. An alternative therapeutic option is to decrease the state of immune activation directly without suppressing viral replication itself. Several immunosuppressive agents have been used for this purpose, such as hydroxurea, ${ }^{13}$ thalidomide, ${ }^{14}$ and cyclosporine $\mathrm{A},{ }^{15}$ but are not attractive for various reasons.

Intravenous immunoglobulins (IVIG) are safely used for several autoimmune disorders characterized by a certain degree of immune activation. ${ }^{16}$ In a previous study ${ }^{17}$ IVIG treatment diminished the increased tumor necrosis factor (TNF)- $\alpha$ activity in HIV-1-infected patients, which was accompanied by a small increase in $\mathrm{CD} 4^{+} \mathrm{T}$ cell count. In the current proof-of-concept study we investigated whether IVIG treatment during chronic HIV-1 infection can mitigate the state of $\mathrm{T}$ cell activation and thus decrease the rate of $\mathrm{CD} 4^{+} \mathrm{T}$ cell turnover.

We included six antiretroviral therapy (ART)-naive adults (median age 39 years, range 31-65) with chronic HIV-1 infection [median $\mathrm{CD}^{+} \mathrm{T}$ cell count 300 (range 200-460) $\times 10^{6} /$ liter and median pVL (Versant HIV-1 RNA 3.0 assay) 5.0 (3.2-5.2) $\log _{10}$ copies $/ \mathrm{ml}$ from our outpatient clinic at the Academical Medical Center in Amsterdam, the Netherlands in this open label, single center study. The primary objective was to evaluate the effect of IVIG on the state of chronic immune activation and the pVL in HIV-1-infected therapy-naive patients. Secondary objectives were to evaluate of the effect of IVIG on complement activation, cytokine production, and immunoglobulin levels.

The hospital Institutional Review Board approved the study and written informed consent was obtained from all participating patients before any study procedure was performed. Exclusion criteria were acute HIV-1 infection (defined as duration of infection $<6$ months), signs or history of AIDS-defining events, IgA deficiency, hypogammaglobulinemia, autoimmune disease, other infectious diseases besides HIV-1 infection, recent or current treatment with immunomodulating or antiinflammatory medication, or a history of allergic reactions against human plasma or plasma products. Female patients were excluded if they were pregnant or lactating. Patients remained in follow-up until 12 weeks after the second dosage, with study visits at day 0,1 , and 4 and week 1, 2, 4, 6, 8, and 16 .

Patients were treated with IVIG (Sanquin Plasma Products, Amsterdam, the Netherlands) at a dosage of $0.4 \mathrm{~g} / \mathrm{kg}$ body weight, at week 0 and 4 , which was well tolerated. Only one patient did not receive the second dosage of IVIG because of nonmedical personal reasons. Immunoglobulin G (IgG) levels [measured by nephelometry (Behring Nephelometer Analyzer, Marburg, Germany), according to standard procedures] showed a peak during the first days after the first dosage and approached baseline levels within 1 week (Fig. 1). After the second infusion at week 4 this peak was not observed, which might be due to less frequent sampling.

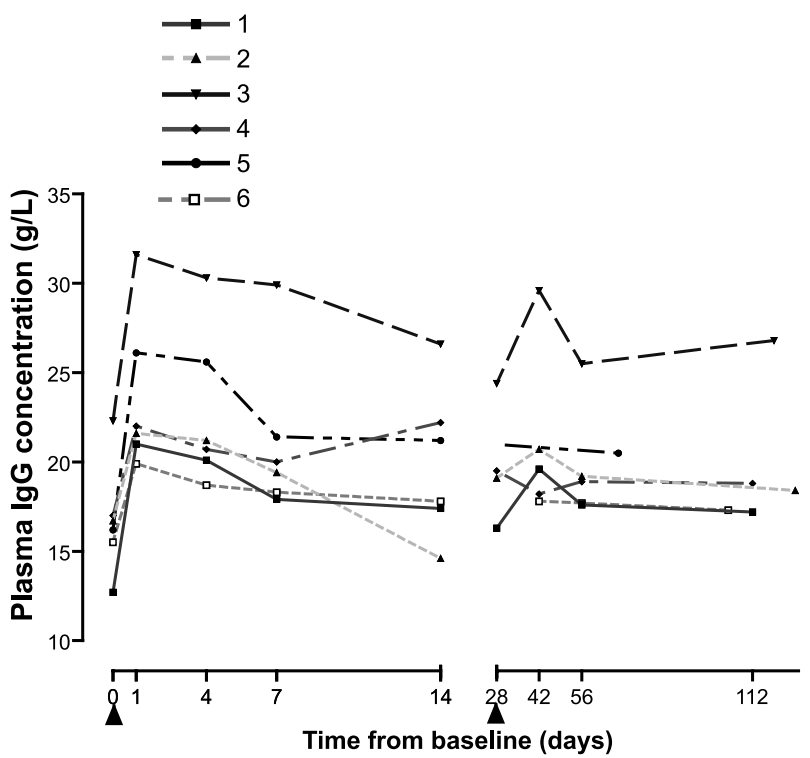

FIG. 1. Plasma IgG levels (g/liter) after administration of IVIG in six HIV-1-infected antiretroviral-naive patients. Arrows indicate the administration of IVIG on days 0 and day 28. Patient no. 5 did not receive the second dosage because of nonmedical personal reasons.

We observed a decrease in flow cytometry analyses during the first 7 days after the first infusion. Compared to baseline levels, the median relative decreases of the proportion of activated lymphocytes in the CD4 and CD8 compartments in the first week were $3.5 \%$ (range $1-7 \%$ ) and $5 \%(1-10 \%)$, respectively ( $p=$ 0.027 for both CD4 and CD8 compartment, Wilcoxon signed rank test, not corrected for multiple testing; Fig. 2). This decrease in activation state was not accompanied by a change in the fraction of proliferating $\mathrm{CD}^{+}{ }^{+}$or $\mathrm{CD}^{+}{ }^{+} \mathrm{T}$ cells measured by $\mathrm{Ki} 67$ expression ex vivo ${ }^{18}$ (Fig. 3). However, we did observe a slight increase in $\mathrm{CD}^{+}$(Fig. 4A), as well as in the $\mathrm{CD}^{+}$and total lymphocyte counts (data not shown). For the CD4 compartment, this increase was significant only on day 4 (median +55 cells compared to baseline, range $0-150, p=0.043$, Wilcoxon signed rank test, not corrected for multiple testing), and for the $\mathrm{CD} 8^{+}$ compartment on day 1 and day 7 ( +60 cells compared to baseline, range $2-72, p=0.027$; and +175 cells, range $70-1040, p=$ 0.028 respectively, Wilcoxon signed rank test, not corrected for multiple testing). We also observed a slight increase in pVL during the first days after IVIG infusion, which was statistically significant on day 1 only (median $+0.13 \log _{10}$ compared to baseline, range $0.1-0.55, p=0.028$, Wilcoxon signed rank test, not corrected for multiple testing; Fig. 4B). None of these changes was statistically significant when repeated measurement techniques were applied.

All parameters returned to baseline levels within a week after the first IVIG infusion. After the second infusion these signs of immune activation and changes in $\mathrm{CD} 4^{+} \mathrm{T}$ cell counts or pVL were not documented, due to the lack of blood sampling during the first days after the second infusion. However, some patients showed some signs of increased $\mathrm{CD} 4^{+} \mathrm{T}$ cell counts and $\mathrm{pVL}$ and decreased activation markers at the time of first sampling, 2 weeks after the second infusion. 
A

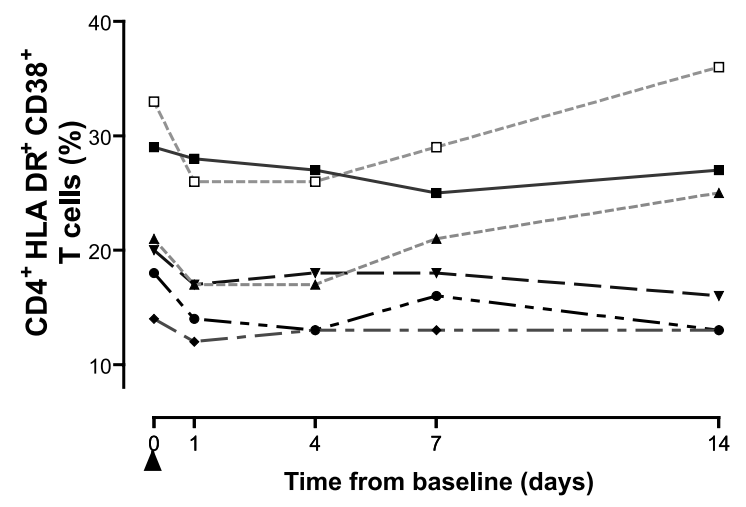

C

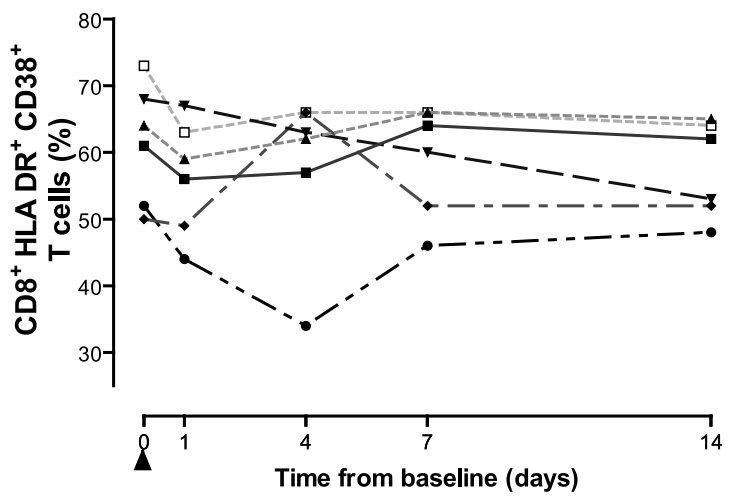

B

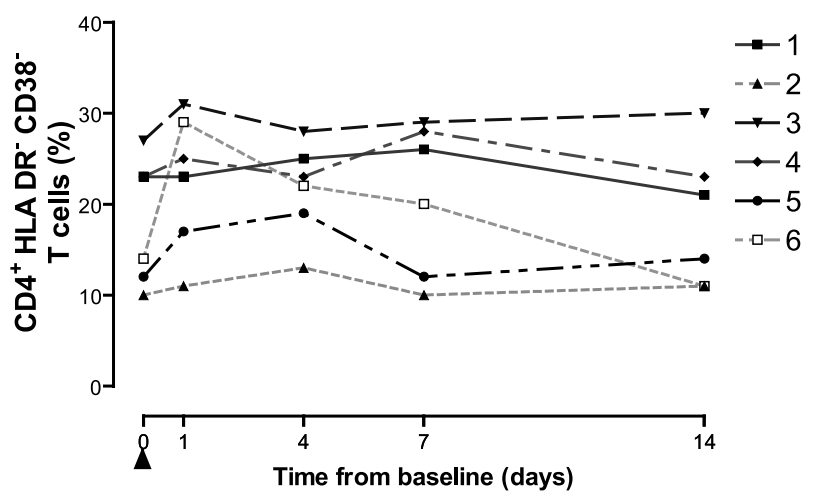

D

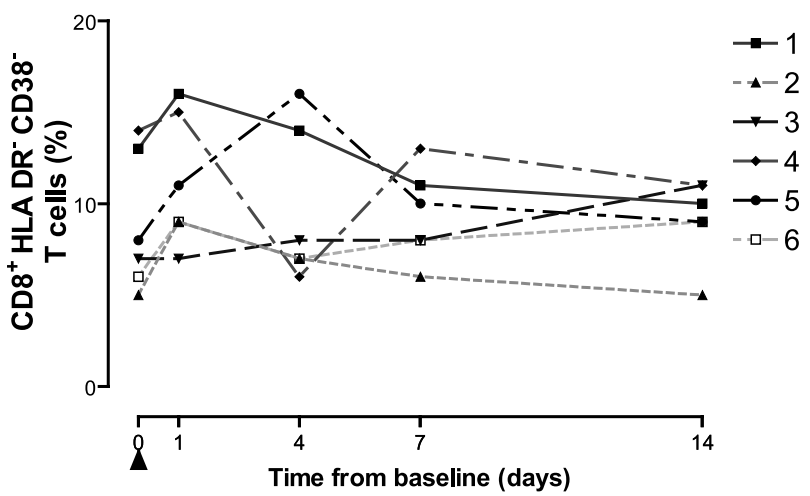

FIG. 2. Percentages of activated $\left(\mathrm{CD} 38^{+} \mathrm{HLA} \mathrm{DR}^{+}\right)$peripheral blood $\mathrm{CD} 4^{+}$and $\mathrm{CD} 8^{+} \mathrm{T}$ cells $(\mathbf{A}$ and $\mathbf{C}$, respectively) and nonactivated $\left(\mathrm{CD} 38^{-} \mathrm{HLA} \mathrm{DR}^{-}\right) \mathrm{CD}^{+}$and $\mathrm{CD} 8^{+} \mathrm{T}$ cells $(\mathbf{B}$ and $\mathbf{D})$ during the first 14 days after the first administration of IVIG (arrow) in six HIV-1-infected antiretroviral-naive patients.

There were no clear changes in the maturation stage of the $\mathrm{CD} 4^{+}$or $\mathrm{CD}^{+}{ }^{+} \mathrm{T}$ cell subsets measured by additional flow cytometry [i.e., \% naive $\left(\mathrm{CD} 45 \mathrm{RA}^{+} \mathrm{CD} 27^{+}\right), \mathrm{CD} 27^{+}$memory $\left(\mathrm{CD} 45 \mathrm{RA}^{-} \mathrm{CD}^{2} 7^{+}\right)$, and CD27 ${ }^{-}$memory $\left(\mathrm{CD} 45 \mathrm{RA}^{-} \mathrm{CD}^{-} 7^{-}\right)$ subsets within the $\mathrm{CD}^{+}$and $\mathrm{CD}^{+}{ }^{+} \mathrm{T}$ cells, and effector $\left(\mathrm{CD} 45 \mathrm{RA}^{+} \mathrm{CD}^{-} 7^{-}\right)$subset within the $\mathrm{CD} 8^{+} \mathrm{T}$ cells, ${ }^{19,20}$ data not shown]. The proliferative capacity of lymphocytes upon stimulation with monoclonal antibodies against CD3 and CD28 $8^{21,22}$ was unchanged (data not shown). In all patients, TNF- $\alpha$, interleukin (IL)-6, and IL-8 (assay Sanquin, Amsterdam, the Netherlands), interferon- $\gamma$, and IL-10 levels (measured as described previously ${ }^{23}$ ) in plasma were below the lower limit of quantification at almost all time points, including baseline. There was also no effect on the levels of the complement factors $\mathrm{C} 3 \mathrm{bc}$ and $\mathrm{C} 4 \mathrm{bc}$, the acute phase protein $\mathrm{CRP}$, or elastase (measured as described previously, ${ }^{24-27}$ data not shown).

In our study, treatment of therapy-naive HIV-infected individuals with IVIG resulted in a small, temporary decrease in T cell activation, as reflected by a reduction of CD38 and HLA DR expression on both $\mathrm{CD}^{+}{ }^{+}$and $\mathrm{CD}^{+} \mathrm{T}$ lymphocytes. Although our data support the hypothesis that chronic immune activation, rather than direct HIV-1 infection, mediates the loss of $\mathrm{CD}^{+}{ }^{+} \mathrm{T}$ cells in chronic HIV-1 infection, the limited number of patients and the lack of a control group do not allow rec- ommendations on the use of IVIG as an immunomodulatory agent in inhibiting immune activation. The relatively small changes in $\mathrm{T}$ cell activation state, $\mathrm{T}$ cell numbers, and plasma HIV-1 RNA were not statistically significant after applying repeated measurements techniques or correction for multiple testing.

We and others have demonstrated that immune hyperactivation associated with HIV-1 infection drives accelerated $\mathrm{T}$ cell turnover, ultimately resulting in $\mathrm{CD}^{+}{ }^{+} \mathrm{T}$ cell loss and disease progression. ${ }^{7,12,28}$ In agreement with this we observed that the decrease in immune activation was accompanied by a slight increase in $\mathrm{CD}^{+}{ }^{+}$and $\mathrm{CD} 8^{+} \mathrm{T}$ cell numbers. However, we did not observe an increase in the percentage of $\mathrm{Ki}^{+} 7^{+}$cells, indicating that the reduction in $\mathrm{T}$ cell activation did not result in an increased $\mathrm{CD}^{+}{ }^{+}$and $\mathrm{CD}^{+} \mathrm{T}$ cell production. The lack of increase in the proportion of proliferating cells suggests that the increase in $\mathrm{CD}^{+}{ }^{+}$and $\mathrm{CD} 8{ }^{+} \mathrm{T}$ cell numbers in peripheral blood most likely resulted from redistribution of lymphocytes from peripheral lymphoid tissues, lungs, or the gastrointestinal tract, similar to the redistribution of $\mathrm{T}$ cells seen after the start of HAART. ${ }^{29}$ The redistribution of $\mathrm{CD}^{+}{ }^{+} \mathrm{T}$ cells after initiation of HAART has been attributed to the decrease in $\mathrm{pVL}$ that is achieved by therapy. However, since in our present study no decrease in viral load was achieved, concomitant with the ab- 

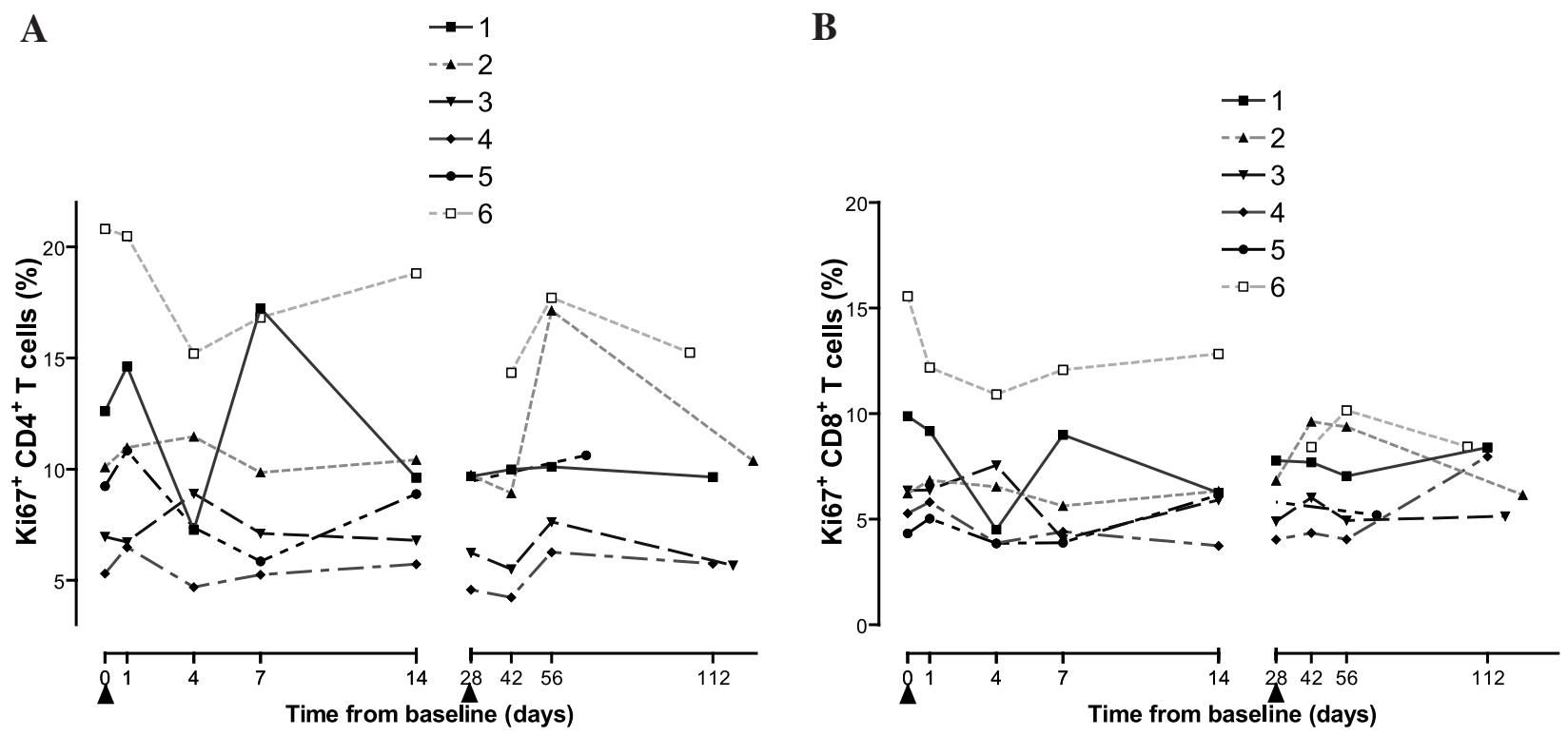

FIG. 3. Percentages of proliferating $\left(\mathrm{Ki}_{67}{ }^{+}\right)$peripheral blood $\mathrm{CD} 4^{+}$and $\mathrm{CD} 8^{+} \mathrm{T}$ cells $(\mathbf{A}$ and $\mathbf{B}$, respectively) after administration of IVIG in six HIV-1-infected antiretroviral-naive patients. Arrows indicate the administration of IVIG on day 0 and day 28 .

sence of a direct antiviral effect of the IVIG preparation on HIV replication in vitro (data not shown), the redistribution of $\mathrm{CD}^{+}$ $\mathrm{T}$ cells observed here more likely is the result of a decrease in immune activation than the result of a decrease in pVL.

Since HIV-1 replicates more efficiently in activated CD4 ${ }^{+} \mathrm{T}$ cells, we expected that the decreased level of immune activation after IVIG administration would result in a lower pVL. Surprisingly, we observed an increase in pVL levels in all six patients during the first days after IVIG administration (Fig. 4B). This increase may have been missed in a previous trial with IVIG in HIV-1-infected patients ${ }^{7}$ because in that study pVL was measured only after 6 days. The increase in $\mathrm{CD} 4^{+} \mathrm{T}$ cells occurred a few days later than the increase in pVL (Fig. 4A), which makes it unlikely that the rise in $\mathrm{pVL}$ was due to an increase of potential target cells for HIV-1 replication. A more plausible expla- nation for the increase in pVL seems to be a temporarily diminished clearance of immune complexes containing HIV-1 virions due to occupation and saturation of Fc $\gamma$ receptors by administered IgG. ${ }^{16,30}$ Furthermore, anti-idiotype antibodies in IVIG may bind to anti-HIV antibodies, thereby inhibiting the opsonization of HIV and reducing the efficiency of clearance via Fc $\gamma$ receptors. ${ }^{16,30}$ Finally, high levels of IgG in blood also saturate FcRn receptors, causing a faster clearance of all $\mathrm{IgG}$, including endogenous anti-HIV-1 antibodies, and thus interfering with opsonization and efficient clearance of HIV-1 virions. ${ }^{31}$ The fact that the increase in pVL was only temporary can be explained by the rapid normalization of IgG concentrations. Alternatively or in addition, anti-idiotypic antibodies that were present in IVIG may have been absorbed by autologous anti-HIV antibodies within a few days after administration.
A

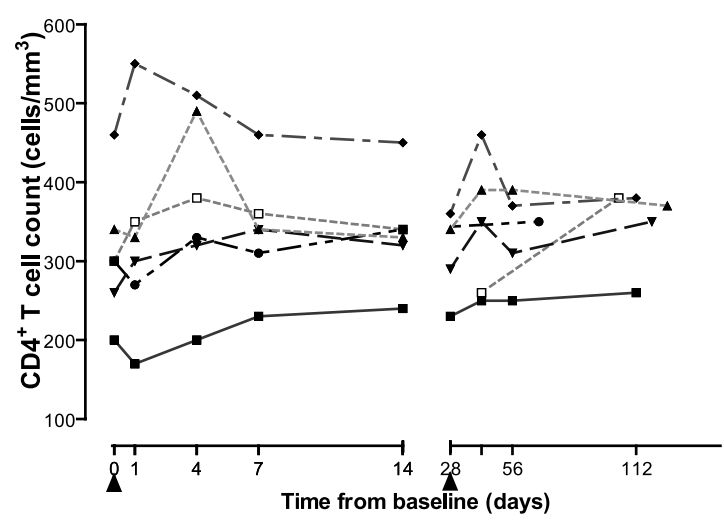

B

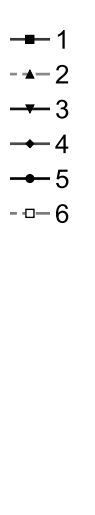

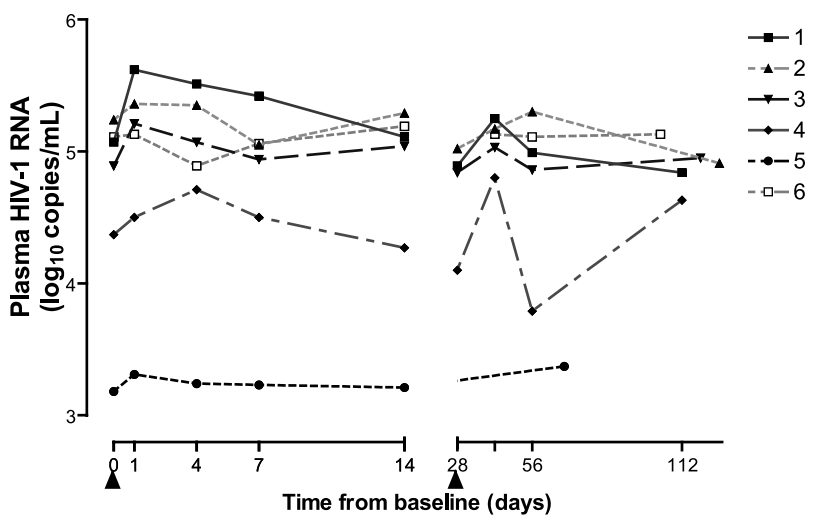

FIG. 4. Peripheral blood CD4 ${ }^{+} \mathrm{T}$ cell count (A) and plasma HIV-1 RNA (B) after administration of IVIG in six HIV-1-infected antiretroviral-naive patients. Arrows indicate the administration of IVIG on day 0 and day 28. 
In a previous study with IVIG in HIV-1-infected patients ${ }^{17}$ the increase in $\mathrm{CD} 4^{+} \mathrm{T}$ cell count was more pronounced than what we observed here. In that study the increase in CD4 $+\mathrm{T}$ cell numbers correlated with a decrease in TNF- $\alpha$ activity. The effect on lymphocyte activation markers was not reported. We did not see any effect of IVIG treatment on TNF- $\alpha$ and other cytokine or complement levels, mainly because these parameters were all below the level of detection at almost all time points. Therefore, the greater increase in $\mathrm{CD} 4^{+} \mathrm{T}$ cell count after IVIG treatment reported previously ${ }^{17}$ could be explained by the lower baseline $\mathrm{CD} 4^{+} \mathrm{T}$ cell counts in that study, with a concomitant higher level of immune activation, ${ }^{32}$ thus allowing relatively more benefit of IVIG treatment.

In conclusion, we observed that IVIG treatment of HIV-1infected individuals resulted in a temporary decrease in immune activation and a concomitant increase of $\mathrm{T}$ cell numbers, despite an increase in HIV-1 antigen exposure. Even though the effects we observed in this study were relatively small as compared to the effects of treatment with HAART and not statistically significant, our results do suggest that immunomodulating therapy in HIV-1 infection could contribute to a prolonged asymptomatic phase. Further studies with more convenient therapies should be performed to evaluate whether immunomodulating therapy can indeed be effective in reducing immune activation and $\mathrm{CD}^{+}{ }^{+} \mathrm{T}$ cell decline, thus delaying clinical progression and the moment that ART needs to be initiated.

\section{ACKNOWLEDGMENTS}

We want to thank the patients for their participation, Marian Nievaard, research nurse, and the nursing staff of the Special Investigation Unit for excellent patient care, Elly Hassink for help on statistics, Edwin van Mirre (Sanquin Research, Department of Immunopathology) for useful comments, Anke Eerenberg (Sanquin Research, Department of Immunopathology) for performing assays, and Paul Strengers (Sanquin Plasma Products) for the kind supply of IVIG.

\section{REFERENCES}

1. Palella FJJ, Delaney KM, Moorman AC, et al.: Declining morbidity and mortality among patients with advanced human immunodeficiency virus infection. HIV Outpatient Study Investigators. N Engl J Med 1998;338(13):853-860.

2. Detels R, Munoz A, McFarlane G, et al.: Effectiveness of potent antiretroviral therapy on time to AIDS and death in men with known HIV infection duration. Multicenter AIDS Cohort Study Investigators. JAMA 1998;280(17):1497-1503.

3. Lee LM, Karon JM, Selik R, Neal JJ, and Fleming PL: Survival after AIDS diagnosis in adolescents and adults during the treatment era, United States, 1984-1997. JAMA 2001;285(10):1308-1315.

4. Mocroft A, Ledergerber B, Katlama C, et al.: Decline in the AIDS and death rates in the EuroSIDA study: An observational study. Lancet 2003;362(9377):22-29.

5. Embretson J, Zupancic M, Beneke J, et al.: Analysis of human immunodeficiency virus-infected tissues by amplification and in situ hybridization reveals latent and permissive infections at single-cell resolution. Proc Natl Acad Sci USA 1993;90(1):357-361.
6. Chun TW, Carruth L, Finzi D, et al.: Quantification of latent tissue reservoirs and total body viral load in HIV-1 infection. Nature 1997;387(6629):183-188.

7. Brenchley JM, Schacker TW, Ruff LE, et al.: CD4+ T cell depletion during all stages of HIV disease occurs predominantly in the gastrointestinal tract. J Exp Med 2004;200(6):749-759.

8. Hazenberg MD, Hamann D, Schuitemaker H, and Miedema F: T cell depletion in HIV-1 infection: How CD4 $+\mathrm{T}$ cells go out of stock. Nat Immunol 2000;1(4):285-289.

9. Swingler S, Mann A, Jacque J, et al: : HIV-1 Nef mediates lymphocyte chemotaxis and activation by infected macrophages. Nat Med 1999;5(9):997-103.

10. Sprent J: Lifespans of naive, memory and effector lymphocytes. Curr Opin Immunol 1993;5(3):433-438.

11. Mohri H, Perelson AS, Tung K, et al.: Increased turnover of T lymphocytes in HIV-1 infection and its reduction by antiretroviral therapy. J Exp Med 2001;194(9):1277-1287.

12. Hazenberg MD, Otto SA, Benthem BHB, et al.: Persistent immune activation in HIV-1 infection is associated with progression to AIDS. AIDS 2003;17(13):1881-1888.

13. Rutschmann OT, Opravil M, Iten A, et al:: A placebo-controlled trial of didanosine plus stavudine, with and without hydroxyurea, for HIV infection. The Swiss HIV Cohort Study. AIDS 1998;12(8):F71-F77.

14. Kaplan G, Thomas S, Fierer DS, et al:: Thalidomide for the treatment of AIDS-associated wasting. AIDS Res Hum Retroviruses 2000;16(14):1345-1355.

15. Rizzardi GP, Vaccarezza M, Capiluppi B, et al.: Cyclosporin A in combination with HAART in primary HIV-1 infection. J Biol Regul Homeost Agents 2000;14(1):79-81.

16. Kazatchkine MD and Kaveri SV: Immunomodulation of autoimmune and inflammatory diseases with intravenous immune globulin. N Engl J Med 2001;345(10):747-755.

17. Aukrust P, Hestdal K, Lien E, et al.: Effects of intravenous immunoglobulin in vivo on abnormally increased tumor necrosis factor-alpha activity in human immunodeficiency virus type 1 infection. J Infect Dis 1997;176(4):913-923.

18. Gerdes J, Lemke H, Baisch H, et al.: Cell cycle analysis of a cell proliferation-associated human nuclear antigen defined by the monoclonal antibody Ki-67. J Immunol 1984;133(4):1710-1715.

19. Baars PA, Maurice MM, Rep M, Hooibrink B, and Van Lier RA: Heterogeneity of the circulating human CD4+ T cell population. Further evidence that the CD4+CD45RA-CD27- T cell subset contains specialized primed T cells. J Immunol 1995;154(1): $17-25$.

20. Hamann D, Baars PA, Rep MH, et al.: Phenotypic and functional separation of memory and effector human CD8 $+\mathrm{T}$ cells. J Exp Med 1997;186(9):1407-1418.

21. Van Lier RA, Boot JH, Verhoeven AJ, et al.: Functional studies with anti-CD3 heavy chain isotype switch-variant monoclonal antibodies. Accessory cell-independent induction of interleukin 2 responsiveness in T cells by epsilon-anti-CD3. J Immunol 1987; 139(9):2873-2879.

22. Van Lier RA, Brouwer M, and Aarden LA: Signals involved in T cell activation. $T$ cell proliferation induced through the synergistic action of anti-CD28 and anti-CD2 monoclonal antibodies. Eur J Immunol 1988;18(1):167-172.

23. Jansen PM, van der Pouw Kraan TC, de Jong IW, et al.: Release of interleukin-12 in experimental Escherichia coli septic shock in baboons: Relation to plasma levels of interleukin-10 and interferongamma. Blood 1996;87(12):5144-5151.

24. Hack CE, Paardekooper J, Smeenk RJ, et al.: Disruption of the internal thioester bond in the third component of complement (C3) results in the exposure of neodeterminants also present on activation products of C3. An analysis with monoclonal antibodies. J Immunol 1988;141(5):1602-1609. 
25. Wolbink GJ, Bollen J, Baars JW, et al: : Application of a monoclonal antibody against a neoepitope on activated C4 in an ELISA for the quantification of complement activation via the classical pathway. J Immunol Methods 1993;163(1):67-76.

26. Wolbink GJ, Brouwer MC, Buysmann S, Ten Berge IJ, and Hack CE: CRP-mediated activation of complement in vivo: Assessment by measuring circulating complement-C-reactive protein complexes. J Immunol 1996;157(1):473-479.

27. Teeling JL, de Groot ER, Eerenberg AJ, et al.: Human intravenous immunoglobulin (IVIG) preparations degranulate human neutrophils in vitro. Clin Exp Immunol 1998;114(2):264-270.

28. Hazenberg MD, Otto SA, Cohen Stuart JW, et al.: Increased cell division but not thymic dysfunction rapidly affects the T-cell receptor excision circle content of the naive T cell population in HIV1 infection. Nat Med 2000;6(9):1036-1042.

29. Pakker NG, Notermans DW, de Boer RJ, et al.: Biphasic kinetics of peripheral blood $\mathrm{T}$ cells after triple combination therapy in HIV1 infection: A composite of redistribution and proliferation. Nat Med 1998;4(2):208-214.

30. Yu Z and Lennon VA: Mechanism of intravenous immune globulin therapy in antibody-mediated autoimmune diseases. $\mathrm{N}$ Engl J Med 1999;340(3):227-228.
31. Bleeker WK, Teeling JL, and Hack CE: Accelerated autoantibody clearance by intravenous immunoglobulin therapy: Studies in experimental models to determine the magnitude and time course of the effect. Blood 2001;98(10):3136-3142.

32. Hazenberg MD, Stuart JW, Otto SA, et al.: T-cell division in human immunodeficiency virus (HIV)-1 infection is mainly due to immune activation: A longitudinal analysis in patients before and during highly active antiretroviral therapy (HAART). Blood 2000;95(1):249-255.

Address reprint requests to: Joost N. Vermeulen IATEC clo Academic Medical Center of the University of Amsterdam Room T0-111 Meibergdreef 9 1105 AZ Amsterdam, the Netherlands

E-mail: j.n.vermeulen@amc.uva.nl 